\title{
Inclusive Policy and Academic Achievements in Mathematics of Student with Special Educational Needs (SEN) in Republic of Serbia
}

\section{Ph.D. Gordana Nikolić}

Associate Professor,

Faculty of Education in Sombor, University of Novi Sad, Serbia

\section{Ph.D. Nataša Branković}

Associate Professor,

Faculty of Education in Sombor, University of Novi Sad, Serbia

Corresponding Author

\section{Ph.D. Bojan Lazić}

Assistant Professor,

Faculty of Education in Sombor, University of Novi Sad, Serbia

\section{Ph.D. Rada Rakočević}

Assistant Professor, Independent University Banja Luka, Banja Luka, Republika Srpska

Doi: $10.2478 / m j s s-2019-0008$

\section{Abstract}

One mechanism for evaluating educational systems for inclusion is through academic outputs of students who are taught in either segregated or inclusive setting. The goal of the research was to examine and compare the academic achievement in Mathematics of students with special education needs (SEN) in the fifth and sixth grade (11-12 years old students) in different educational settings in the Republic of Serbia. In this study, 175 students from 11 special and 7 regular schools participated in the research. Assessment results demonstrated statistically significant differences achievement for students in sixth grade in special schools compared to students with SEN in the same classes of regular schools. At fifth grade level there was no statistical difference between the students in special and regular schools. We discuss possible reasons why differences may or may not exist, including distinguishing between inclusion and integration as well as sociohistorical differences in grade levels.

Keywords: inclusive education, inclusive policy, academic achievement in mathematics, special educational needs, students with learning disabilities, Serbia

\section{Introduction}

Inclusive education (IE) became a part of the Republic of Serbia's law in 2009. At the time of this study, the law was in place for eight years, yet segregated schooling still existed. Despite widespread policy support for inclusion, the dual approach to education (in special and regular 
settings schools) is still supported by some parents and professionals of children with disabilities. Policy-level integration into European and international norms around inclusion is sometimes met with suspicion that regular schools may not be the most appropriate setting for students with disabilities. The purpose of this study examine output differences in the effects of special and regular schools in Mathematics. These outputs may be indicators of inclusive education quality (United Nations 2016) and may evaluate whether or not placing children in regular schools is enough to consider the placement inclusive. The latter is a systemic change process that focuses on the presence, participation, and achievement of all (Ainscow \& Miles 2008).

Teaching practice for children for SEN has been historically shaped in the Republic of Serbia by Lev Semyonovich Vygotsky (1925). Vygotsky's conceptualisation of defectology has been a professional focus for special educators for decades in Russia, Central Europe, and Eastern Europe. The historical practice of defectology was not to necessarily change curriculum for SEN but to provide specific supports in compliance with individualized development maps for students with significant disabilities (Vygotsky, 1996). These philosophies carried over to children with a variety of learning challenges, including students with more mild learning disabilities (LD). In Serbia, defectological practices been applied with students with LD, although some scholars have argued that students with LD can be equally successful as non-disabled students as long as classroom practices are accessible to them (Edyburn, 2003). The mark that Vygotsky left as a pioneer of contemporary approach in the field of special education has been slow to change in the Republic of Serbia. Therefore, the special education of students with LD has traveled a somewhat rocky road of false starts, misconceptions, and misinformed ideas-until 10 years ago, when contemporary research on the teaching of children with Learning Disabilities became more widely accepted (see, for example, Kavale \& Forness, 2000, Shin \& Pedrotty, 2015, Swanson, 1999, Vaughn, Gersten, \& Chard, 2000) and used for program planning.

The current state of policy and practice in Serbia is a complicated mix of special schooling informed by defectology - and a policy movement toward inclusive education. The system itself is very much in flux. Engsig \& Johnstone (2015) highlighted similar circumstances in Denmark, concluding that policy transfer does not likely happen wholesale in the inclusive education efforts. Because inclusive education is multidimensional, policy transfer or borrowing may be more nuanced, with different policies influencing different narratives. The authors concluded that in order to understand why such external policies may influence internal models, knowledge of the cultural aspects of the country in question is necessary.

A major question in the inclusion movement, which is highly relevant current trends in Serbia, is that of the educational effectiveness of regular and special schools as sites of education for students with special educational needs, including learning disabilities. Contemporary practices with the strongest evidence base, according to (Vaughn et al., 2003), begin by identifying students' processing difficulties and matching treatment practices to these difficulties. This medical or pathology-oriented emphasis on underlying mechanisms related to student deficits, however, may such a focus may create undue focus directed to remediating process difficulties and too little focus on instructing students in their target areas of need (e.g., reading, math, or content areas). On the other hand, at least with respect to the education that students with LD receive within general education, if instruction is undifferentiated and is not specifically designed to meet the instructional needs of the student, children with LD may languish in general education environments (Baker \& Zigmond, 1995, Zigmond, 2003). In the case of Serbia, a dual dilemma exists in that special schools are primarily focused on deficiencies of students while regular schools may promote social inclusion, but do little to support the academic success of children with LD (Popović \& Nikolić, 2015).

The dualities described above are not unique to Serbia. In fact, the tensions between special and regular schooling approaches may be characterised by three terms: segregation, integration, and inclusion. Segregation is defined as any schooling that takes place in non-regular school environments. Integration and inclusion are more nuanced because they likely occur in the same schooling environments (regular schools). Vislie (2003) noted the difference between integration and inclusion were sometimes confused, but had different core foci worth noting. Integration, for example, has three key functions: 1) rights to schooling and education for children with disabilities; 
right to education in the local schools; and reorganization or the special needs education system to allow for greater participation within the regular school environment. According to the author (2003), integration was a policy- and systems-level initiative but had very little to do with teaching and learning in the classroom.

Inclusion, on the other hand, is a classroom-based phenomenon. It is a process for overall school effectiveness that considers inclusion and exclusion as interconnected principles. Its main focus is the overall restructuring of curriculum and instruction to be more responsive to diversity.

Bhattacharya (2010) explained why "inclusion" and "integration" are often commodified. According to the author, inclusion and integration may even be used simultaneously in sentences to describe the difference between schooling in mainstream schools and that of special schools. However, the difference is in the education itself. Bhattarcharya suggested that in comingled inclusion/integration discourse, special schooling and special needs education are also comingled so that children are perceived to either need special schooling (where they would receive special needs education) or integrated/inclusive education where there is a 'cursory' thought that children may need extra time or assistance. Bhattarcharya warns that the semantic proximity of inclusion and integration, however, poses a danger because implicit in integration is the notion of assimilation of all children into an existing model. On the other hand, inclusion necessitates change in the school and classroom itself, where strategies once only employed for children with special needs are deployed for the benefit of all children (Rouse \& Florian, 1996). This may require changes in philosophy (Naicker, 2015); curricular reform (Naicker, 2015); individualization of resources and staffing patterns (Mastropieri \& Scruggs, 2001).

In sum, moving children from segregated to regular schools does not necessarily constitute inclusion. To this end, such a shift, without the appropriate philosophical and support frameworks, may result in unexpected outcomes in relation to the participation and performance of students with special educational needs in regular education classes. One mechanism for evaluating the educational effectiveness of inclusion is through educational assessment. Such outputs measures provide professionals with a performance-based understanding of how content is understood in class. Although the words inclusion and integration imply a processual approach, simple outcomes data my help indicate if a child is truly included (by way of a systems-change approach that is designed to ensure equal opportunities) or simply integrated (physically present and potentially socially engaged, but without educational supports).

In this study we compared assessment outputs in mathematics to determine if students in special/segregated schools were performing at the same achievement level that students in regular, so-called inclusion classes. The paragraphs be low outline our research process for two academic groups.

\section{Theoretical Framework}

About $1.5 \%$ of children in Serbia attend special schools. A very small number of children (less than $1 \%$ ) with SEN may also attend school in separate classes within regular schools or, if a student has a profound disability, may stay at a full-time residential and therapeutic institution (Nikolić, Lukić \& Janković, 2010). Therefore, children with LD most often receive their education either in a special school or a regular classroom (with few exceptions for separate classrooms in regular schools). The duality described is likely the result of policy shifts that occurred in the late 2000s. After 2000, a proinclusive policy was developed, giving rise to several strategic documents: The Analysis of the Current Situation and Proposals for Reforms of Education for Children with Special Needs (Serbian Ministry of Education and Sport [SmoEaS] 2003a), the Educational Strategy for Children with SEN (SmoEaS 2003b) and The Law on the Prevention of Discrimination Against Persons with Disabilities (RS, 'Official Gazette RS' No. 33/06) (Galović, Brojčin \& Glumbić, 2014).

The 2009 Law on Basis of System of Education LBSE ("Official Gazette RS" No. 72/09, 52/11, $55 / 13,35 / 15)$ provided the legal right for all children have an equal opportunity to education. The law called for accessibility of school practices and that such accessibility should be provided without discrimination and exlusion of children from marginalized and vulnerable social groups, including children with disabilities (Article 3). Under this law, pupils with SEN have the right to 
curriculum adaptation by using an individual education plan (IEP).

Together with additional educational support at all levels of education (Article 77), the Republic of Serbia also adopted the("Official Gazette RS," No.72/12), whichset the following priorities and main objectives for SEN development: 1) increasing coverage of children with SEN enrolled in schools; 2) enhancing quality of the inclusive process and student outcomes; 3 ) increasing efficiency and 4) attaining and maintaining relevance of the Education system. Based on the identified key challenges and barriers, the SED 2020 defines mechanisms for assuring accessibility, equity and quality of students with SEN as rights-bearing students (Nikolić \& Nedeljković, 2015). By law, students with LD then could expect to be fully included in regular schools and be participants in a high quality teaching and learning environment.

Therefore, the purpose of this study was not to evaluate whether or not placing students with LD "works." The move to inclusion appears to be a foregone conclusion for the Republic of Serbia. Over the past five years there has been a downward trend in the number of children being educated in special schools. According to the data from the schools that participated in this study, in the past seven the number of students who were educated in special schools decreased by $11.49 \%$. At the same time, participation in special classes of regular schools for students with disabilities also decreased by $25 \%$ ) students between 2009-2015, while the number of students with disabilities increased by $348(49.64 \%)$ in regular classes of these schools over a five-year span.

Specific to the population in this study, students with high-incidence disabilities (i.e., learning disabilities [LD], emotional and behavioral disorders [EBD], mild intellectual disabilities [ID], sensory and attention deficit hyperactivity disorder [ADHD] and autism spectrum [AS]) are also more present in the general classrooms across the Republic of Serbia since 2009. According to the Ministry of Education, Science and Technological Development (MinESTD) and UNICEF office in the Republic of Serbia, the total number of students that are being educated with an individualized or adapted curriculum (Individualized Education Programme - IEP) in the general classrooms has increased by 33.1 percent between 2009 and 2016, while at the same time the total number of students educated in 48 special schools decreased by 15 percent (MinESTD, UNICEF, 2015). Our analysis, then, focused on the educational outputs of a system in transition, in order to learn what may or may not be missing in the milieu of schools that are newly inclusive.

\section{Research Methods}

This study examined mathematical outputs on an achievement test based on national standards. The study compared students in two different educational settings (special school, regular school) but did not involve evaluation of the overall teaching processes. Based on policy, history, and the authors' experience in schools in the Republic of Serbia, it was assumed that special schools provided small group settings while students were part of an either integrated or inclusive classes in regular schools.

\subsection{Sample}

In total, 175 students with identified Learning Disabilities (LD) actually are students with mild intellectual disability MID. According to the International Statistical Classification of Diseases and Related Health Problems, 10th revision (WHO, 1992) Characteristics of students with MID is significant deficit in intellectual development (IQ score 55-69) and significant limitation in adaptive functioning (ICD-10). Data about students diagnosis and level of intellectual deficit were collected from students school files, in cooperation with specialist service of the school. All respondents in their school records had the decision of the Interested comission for determining educational support, with the stated estimated need for adapting the content of subject mathematic in relation to regular curriculum. The pupils were distributed across 11 special and 7 regular schools. Among the participants, 109 attended a regular school while only 66 pupils attended special schools. The sample included 96 Grade 5 pupils and 79 Grade 6 pupils. Table 1 (below) demonstrates the distribution of the sample across type of school and grade. All students in the sample had 
individualized education plans and received some form of adaptation to the mathematical curriculum.

All students, in both, regular and special schools, have three times a week additional support after classes in the subject of mathematics. Differences in working conditions for the benefit of pupils of special schools are small classes of up to 8 students and teachers with more experience working with MID students. The advantage of pupils in regular schools was peer support during math classes.

Table 1. Sample structure in regards with the grade and type of school

\begin{tabular}{llccc}
\hline & & \multicolumn{2}{c}{ Grade } & \multirow{2}{*}{ Total } \\
\cline { 3 - 4 } & $5^{\text {th }}$ & $6^{\text {th }}$ & \\
\hline Type of school & Regular & 60 & 49 & 109 \\
Total & Special & 36 & 30 & 66 \\
\hline
\end{tabular}

\subsection{Instruments}

In order to test the outputs of educational settings, mathematics tests were constructed by a mathematics and disability expert. Separate tests were constructed for fifth and sixth grade based on mathematics standards across a range of grade levels (both adapted and age-appropriate constructs were tested). A distinctive feature of mathematical cognitive development for 11-12 year olds is reversibility in thinking, which allows the child to master the conservation of volume, mass and number. These reversible functions are characteristic for pupils at the age of about eight onwards. For the purposes of this assessment, tasks on use of concrete logical operations as well as reversible concepts.

The test for Grade 5 contained 12 items while the Grade 6 test contained 14 items. The items were prepared on the basis of the adapted learning and skills standards based on current mathematical materials used (e.g., textbooks) and the curricular experience of the first, third, and fourth authors of this manuscript. These tests are currently published in the manual for working with Students with SEN from fifth to eighth grade in the Republic of Serbia.

\subsection{Procedures}

Tests were distributed to schools located in various school districts throughout the territory of the Republic of Serbia. Mathematics teachers in schools were given explicit instructions on how to test the students in cooperation with the representatives of the schools' specialist service who both ensured all necessary testing accommodations were in place and returned the test to the authors without checking them. The authors then marked the tests based on the keys given for each individual item.

\section{Results of the Analysis}

Independent sample t-tests were conducted to compare scores between students who attend regular and special schools. Each grade level was considered its own sample so that there were not spurious effects introduced by differences in mathematical content. Our aim was to determine if there was a statistically significant difference in children's output scores by school setting.

Despite the policy shift toward inclusion and the requirement that teaching and learning processes be responsive to the needs of children with LD, output indicators revealed that there was no substantive difference between how students with LD scored on mathematics assessments by school site for Grade 5. Results from the Grade 6 assessment indicated a statistically significant difference in scores in favor of children who attended special schools. Table 2 provides basic descriptive statistics for the results of the assessment.

The range of scores for Grade 5 students was between 6 and 74 points, while in case of 
Grade 6 students it was between 2 and 68 points. Curvature and flatness distribution values point out that the summative test scores were normally distributed in the sample.

Table 2. Descriptive indicators of the success in Mathematics test for fifth and sixth grade students

\begin{tabular}{|c|c|c|c|c|c|c|c|c|c|c|}
\hline \multirow[b]{2}{*}{$5^{\text {th }}$ Grade } & \multirow{2}{*}{$\begin{array}{l}\mathrm{N} \\
96\end{array}$} & \multirow{2}{*}{$\begin{array}{l}\text { Min } \\
6.00\end{array}$} & \multirow{2}{*}{$\begin{array}{l}\text { Max } \\
74.00\end{array}$} & \multirow{2}{*}{$\begin{array}{l}\text { Mean } \\
38.43\end{array}$} & \multirow{2}{*}{$\begin{array}{c}\text { SD } \\
16.88\end{array}$} & \multirow{2}{*}{$\begin{array}{c}\text { Variance } \\
285.01\end{array}$} & \multicolumn{2}{|c|}{ Skewness } & \multicolumn{2}{|c|}{ Kurtosis } \\
\hline & & & & & & & -.13 & .25 & -.66 & .4 \\
\hline $6^{\text {th }}$ Grade & 79 & 2.00 & 68.00 & 26.24 & 18.47 & 341.16 & .71 & .27 & -.63 & .53 \\
\hline
\end{tabular}

As noted above, our independent samples $t$-tests demonstrated that there was no statistical difference between students in special or regular schools on mathematics outputs in Grade 5 ( $\mathrm{t}_{(94)}$ $=-.44, p>.05$ ). However, surprisingly, Grade 6 students performed statistically significantly better on mathematical assessments. Independent-samples t-tests demonstrated resulted in meaningful differences inmean scores achieved between students in regular school $(M=20.55, S D=13.56, n$ $=49$ ) and students in special school $(M=35.53, S D=21.66, n=30)$. Results were at the .01 level of significance $(\underline{t}=3.40, \underline{d f}=43.09, \underline{p}<.01,95 \% \mathrm{Cl}$ for mean difference 23.86 to 6.10$)$. Tables 3 and 4 (below) provide an overview of results for children at both grade levels.

Table 3. Results of t-test and Descriptive Statistics for Score on Mathematics Test by Type of School - 5th Grade

\begin{tabular}{|c|c|c|c|c|c|c|c|c|c|c|}
\hline & \multicolumn{6}{|c|}{ Type of school } & \multirow{3}{*}{ 95\% Cl for Mean Difference } & \multirow[b]{3}{*}{$\mathrm{t}$} & \multirow[b]{3}{*}{ df } & \multirow[b]{3}{*}{$p$} \\
\hline & \multicolumn{3}{|c|}{ Regular } & \multicolumn{3}{|c|}{ Special } & & & & \\
\hline & $\mathrm{M}$ & SD & $\mathrm{n}$ & M & SD & $\mathrm{n}$ & & & & \\
\hline $5^{\text {th }}$ Grade & 37.82 & 16.27 & 60 & 39.44 & 18.05 & 36 & $-8.72,5.47$ & -.44 & 94 & .65 \\
\hline
\end{tabular}

Table 4. Results of t-test and Descriptive Statistics for Score on Mathematics Test by Type of School - 6th Grade

\begin{tabular}{|c|c|c|c|c|c|c|c|c|c|c|}
\hline & \multicolumn{6}{|c|}{ Type of school } & \multirow{3}{*}{ 95\% Cl for Mean Difference } & \multirow[b]{3}{*}{$\mathrm{t}$} & \multirow[b]{3}{*}{ df } & \multirow[b]{3}{*}{$\mathrm{p}$} \\
\hline & \multicolumn{3}{|c|}{ Regular } & \multicolumn{3}{|c|}{ Special } & & & & \\
\hline & $\mathrm{M}$ & SD & $\mathrm{n}$ & $\mathrm{M}$ & SD & $\mathrm{n}$ & & & & \\
\hline $6^{\text {th }}$ Grade & 20.55 & 13.56 & 49 & 35.53 & 21.66 & 30 & $23.86,6.10$ & 3.40 & 43.09 & $.00^{* *}$ \\
\hline
\end{tabular}

\section{Discussion}

One shortcoming of assessment studies is that they can explain what a result is without explaining what processes may have led to such results. In this case, Grade 5 students with LD in regular schools performed equally well as those who were in special schools. We may then conclude that setting does not necessarily matter in regards to mathematical outputs and that students can find equal results in both settings.

However, differential results in Grade 6 may present a rationale for special school advocates to call for an end to inclusion policies, noting that mathematical outputs (at least in this study) for students with LD were better in special schools. We believe there are more contextual factors at work, however, than just the location of student learning. We base this rationale on literature that states that inclusion is more than a policy and location issue - it is a teaching issue. Specific teaching strategies and individualized planning are critical ingredients to the special needs education found in special schools. However, it is not the location that makessuch education particularly "special" or effective. In 2003 in the United States, Zigmond found general education environments were not supportive places because they were designed for (and largely adhered to) large-group instruction focused on average or typical learners.

In general, the relationship between special needs education and inclusive education is tensional (Vislie, 2003). Inclusion is designed to create systems with flexible enough curricula so 
that any student can find pathways to success (Naicker, 2015). In an inclusive environment, every child is equal and systems adjust to the needs of children. However, Donati (2006) cautions that inclusion and education for children with special needs may be incompatible. According to the author, in classrooms and societies where effectiveness, efficiency, productivity, and capacity are core values, so-called non-productive citizens (i.e., those who cannot learn in standardized formats) may be seen as a drain on the system. Once these children are identified as 'different' they become problematic to mainstream schools and teachers. Once deemed a problem, it becomes easier to transfer the responsibility to 'specialists' trained to deal with the 'problems' exhibited by the child. (Emmanuelson, 2001).Such a model explains why special schools still exist in the Republic of Serbia.

At the same time, we suggest that the results of this study relate to questions asked by Dyson and Gains (1993) and Dyson et al. (2004). Evidence from inclusive schools (Dyson et al. 2004) and special schools (this study) demonstrates that students with LD can learn mathematics. The question is why these students are not learning mathematics at a higher level in regular schools (which is an expected outcome of inclusion). The answer may lie in a reconceptualization of the constructs of LD and special needs education in regular schools (Ainscow, Farrell \& Tweddle, 2000). The answer to improving outcomes for students with disabilities in inclusive environment is likely not a wholesale reproduction of the special education practices found in special schools, which would take place in segregated classrooms in regular schools (Vislie, 2003).

However, some of the practices in such environments are clear and have strong empirical support. For example, in special schools, students consistently may work with low teacher - student ratios, may have individualization of instruction, may be required to have on-task behavior, and may receive constant teacher monitoring and feedback (Elbaum et al., 2000, Thurlow et al., 1993). In general, small group sizes and direct instruction predict higher achievement in content areas (Lou et al., 1996, Swanson, Carson \& Sachs-Lee, 1996), yet it is likely not a teaching approach in regular schools.

In regular schools, teachers lecture and may not individualize goals for any students, including those with LD. Those who cannot succeed in such environment are, as stated above, perceived to be pathologic or deficient. Dyson and Gains (1993) suggest, then, that different questions need to be asked and a new language in schools is necessary. Rather than ask what is wrong with children, Dyson and Gains suggest that school conversations revolve around why students are failing to learn, how teachers are failing to teach, and what needs to be done to help teachers do their work more effectively.

As noted above, some of the answers to these questions may ironically lie in the special schools themselves. One of the likely reasons for our results is that the pedagogues in special schools have continual and systematic experience of working with Students with SEN. Because inclusion is a relatively new initiative the Republic of Serbia, classrooms are more diverse than they ever have been in the past. Grade 5 and 6 teachers will likely be in their early years of working with students identified as having LD and likely lack capacity or experience to transform their classrooms in order to be more inclusive and effective. Only $30 \%$ of the teachers deem themselves sufficiently prepared after eight years of the introduction of inclusion into schools in the Republic of Serbia (Popović \& Nikolić, 2015). Although changing, it is likely that many regular primary teachers express insecurity because of insufficient preparedness for working in inclusive classrooms. This is particularly relevant for subject teachers in elementary schools who did not have the opportunity to get familiar with the supportive, inclusive methodologies during their basic studies or with follow-on professional development trainings conducted by the government and non-governmental organizations.

The insecurity and ill-preparedness described above raises questions regarding the adequacy of teachers' training in the methods and techniques necessary to effectively work in inclusive classes (cooperative learning, co-teaching, peer tutoring, etc.) (Stenhoff \& Lignugaris-Kraft, 2007, Mitchell, 2010, Friend et al., 2010).

Another important advantage of special schools is the average 1:5 students-teachers ratio, which enables a full scope of individualization during the class for every student a teacher or a special pedagogue guides and corrects during studying and solving tasks. While this may not be 
possible in regular schools, small grouping within classes can be a very effective strategy. Because regular teachers are on the front lines of inclusive education, and because they express a lack of confidence in teaching in diverse classrooms, information sharing with special education teachers may be critical to the support of inclusion.

For example, Brophy (1986) noted that students with SEN achieve more when their teachers clearly emphasize academic objectives, establish high expectations, and allocate the needed time to ensure that academic learning time is maximized. A best practice for students with LD is to pace students through the curriculum briskly but in small steps that allow high rates of success and adapt curriculum materials based on their knowledge of students' characteristics (Brophy, 1986). Given the concerns of teachers and the results of mathematics assessments, it is unlikely that the strategies above are being implemented.

Finally, the shift to more inclusive placements for students with disabilities requires teachers to find new methods to engage and provide feedback to students. One of the most effective mechanisms for providing frequent feedback to students is Class Wide Peer Tutoring (CWPT) that was developed all the way in 1980 by a project at the University of Kansas and then implemented in special education environments (Maheady, Harper \& Mallette, 2003). By involving peers in providing feedback and reinforcement of skills, learning may accelerate. In general, cooperative learning strategies that incorporate individual accountability and group rewards are more likely to improve achievement of students with disabilities (McLeskey et al., 2014).

In this section we provided context to the results of the study. We posited that inclusion is still a relatively new phenomenon in the Republic of Serbia ant that general education teachers do not have the preparation or confidence to yet adequately address newfound diversity in their classrooms (Popović \& Nikolić, 2013). However, potential solutions to the comparatively low achievement of students with LD in regular schools can be found in some of the strategies currently being used in the Serbian special schools. Small groups, appropriate pacing, frequent feedback, and peer-to-peer learning have all been demonstrated to be effective for students with LD and are not necessarily location-bound. Such strategies could be enacted in either a special school or an inclusive regular school. In regular schools, it is likely that positive benefits would be incurred beyond just students with LD.

\section{Conclusions and Way Forward}

Vislie (2003) noted that results without theory can be useless. In this final section we outline why the mathematics assessment utilized in this study may have shed light on acts of integration rather than inclusion in the Serbian schools sampled. We begin this argument by addressing Grade 6 results. From a medical model of disability perspective, children in regular schools should have fared better. By law, special schools in the Republic of Serbia enrol only students with more significant disabilities by recommendation from the students with SEN's guidance committee. If based on predictive elements related to significance of disability, we would expect children with mild to moderate disabilities (who attend regular schools) to have greater mathematical outputs. However, the poor results of children in regular schools were similar to Mathematics results that were obtained during 2012/13 school year when students in third grade of regular and special schools were also tested (Popović \& Nikolić, 2013). Bearing in mind that five years had passed since the first assessment to the current, one might expect that during that period the teachers' competencies for working with Students with SEN were improved. However, in a model that focuses only on students' presence and perhaps their social integration, academic results may suffer.

To this end we argue that the Republic of Serbia's inclusive education policy has not yet produced inclusive environments, but a form of physical presence that better resembles a what Ainscow \& Miles (2008) call at "business as usual" approach to teaching and learning. In such an environment, children with more intensive learning needs than the so-called average child would be unlikely to make achievement gains in the regular education classroom. Ainscow \& Miles (2008) noted that inclusion is both a matter of focusing on all children and focusing on those who are most marginalized. In this setting, those most marginalized would need extra, supplemental, or different 
instruction. Mastropieri and Scruggs (2001) described the most effective inclusive classrooms as those which: have administrative support, appropriate curriculum for diverse learners, support from special education personnel, teachers with effective general teaching skills, have accepting and positive classroom atmospheres, utilize peer assistance and utilize disability-specific teaching skills.

In the area of mathematics, such instruction would include teaching about both the skills and strategies needed to solve problems, with a degree of flexibility not currently present in teaching.

At the end of study, it may be that the Republic of Serbia is still engaged in a staged process of inclusion. Rodriguez \& Garro-Gil (2014) differentiate concepts of inclusion and integration for children with disabilities. They draw upon Buchem's (2013) characterization of 'stages' of: 1) exclusion; 2) segregation; 3) integration; and 4) inclusive. The two latter stages say volumes about approaches to educating children with disabilities. For example, in the integration stage, public schools are required to create space for children with disabilities so they can socialize and learn as best as possible, which may include time out of the classroom for specialized services and learning environments. However, at this stage the onus of academic success falls upon the student. In short, teachers go about their work as they always have and students either succeed or not on the basis of their personal merits, strengths, and challenges.

The arguments are nuanced and become especially challenging when children with disabilities are placed in regular education settings (so-called inclusion) but without the benefit of supplementary services within those environments. Such placement' or physical inclusion may be better termed 'incomplete inclusion,' 'partial integration,' or 'pre-inclusion.' Incomplete inclusion suggests that the children with special needs have accessed the mainstream national curriculum outlined in Salamanca and its follow-on proclamations, but are not receiving the rights-based educational supports and accommodations needed to be successful in such an environment.

These propositions are supported from other studies show that students who have a need for additional support do not produce lower academic achievements in regular than in special schools (e.g. Dyson et al., 2004). In Great Britain, the achievement of students with LD were monitored and tested in 49 special and regular schools for a six-month period. The results confirmed that additional support influenced better results, as well as a more assertive approach of teachers working with students working with SEN, regardless of the type of school the students are educated in, that is, the teachers are working in.

\section{Acknowledgements}

Part of the funding for this paper was provided by the Ministry of Education, Science and Technological Development of the Republic of Serbia, under the project "Digital media technologies and socio-educational changes", no. 47020 (2011-2017).

\section{References}

Ainscow. M., Farrell, P. \& Tweddle, D. (2000). Developing policies for inclusive education: a study of the role of local education authorities. International Journal of Inclusive Education, 4 (3), 211-230.

Ainscow, M. \& Miles, S. (2008). Making Education for all inclusive: Where next?, Prospects 37(1), 15-34.

Baker, J. M.\& Zigmond, N. (1995). The meaning and practice of inclusion for students with learning disabilities: Themes and implications from the five cases. The Journal of Special Education 29, (2), 163-180.

Bhattacharya, T. (2010). Re-examining issue of inclusion in education. Economic and Political Weekly, (April 17), 18-25.

Brophy, J. (1986). Teacher influences on student achievement. American Psychologist, 10, 1069-1077.

Buchem, I. (2013). Diversität und Spaltung. En: Ebner, Martin. and S. Schön, Sandra (Eds.). Lehrbuch für Lernen und Lehren mit Technologien. 2a ed. Berlin: Epubli GmbH. ispep:

Donati, P. (2006). Repensar la Sociedad, Madrid: Ediciones Internacionales Universitarias.

Dyson, A. \& Gains, C. (1993). Special needs and effective learning: towards a collaboration model for the year 2000. In: A. Dyson and C. Gains (Eds.) Rethinking Special Needs in Mainstream Schools towards the year 2000. London: David Fulton.

Dyson, A., Farrell, P., Polat, F., Hutcheson, G. \& Gallannaugh, F. (2004). Inclusion and Pupil Achievement. Newcastle, UK: University of Newcastle, Department for Education and Skills. 
Edyburn, D. L. (2003). Measuring assistive technology outcomes in mathematics. Journal of Special Education Technology, 18 (4), 76-79.

Elbaum, B. E., Vaughn, S., Hughes, M.T. \& Moody, S.W. (2000). How effective are one-to-one tutoring programs in reading for elementary students at risk for reading failure?. Journal of Educational Psychology, 92. 605-619.

Emmanuelson, I. (2001). Reactive versus proactive support coordinator roles: an international comparison. European Journal of Special Needs Education, 16 (2), 133-142.

Engsig, T. \& Johnstone, C. (2015). Is there something rotten in the state of Denmark? The paradoxical policies of inclusive education-lessons from Denmarkn. International Journal of Inclusive Education, 19 (5), 469486.

Friend, M., Cook, L., Hurley-Chamberlain, D. \& Shamberger, C. (2010). Co-teaching: An illustration of the complexity of collaboration in special education. Journal of Educational and Psychological Consultation, 20 (1), 9-27.

Galović, D., Brojčin, B., \& Glumbić, N. (2014). The attitudes of teachers towards inclusive education in Vojvodina, International Journal of Inclusive Education, 12, 1262-1282.

Kavale, K. A. \& Forness, S.R. (2000). Policy decisions in special education: The role of meta-analysis. In R. Gersten, E. P. Schiller, \& S. Vaughn (Eds.), Contemporary Special Education Research, Mahwah, NJ: Erlbaum.

Lou,Y., Abrami, P.C., Spence, J.C., Poulsen, C., Chambers, B. \& D'Apollonia, S. (1996). Within-class grouping: A meta-analysis. Review of Educational Research, 66, 423-458.

Maheady, L., Harper, G. F. \& Mallette, B. (2003). Class-wide peer tutoring. Current Practice Alerts. 8, 1-4.

Mastropieri, M. A., \& Scruggs, T. E. (2001). Promoting inclusion in secondary classrooms. Learning Disability Quarterly, 24 (4), 265-274.

McLeskey, J., Waldron, N., Spooner, L., F. \& Algozzine, B. (2014). Handbook of Effective Inclusive Schools: Research and Practice. New York, London: Routledge.

Mitchell, D. (2010). Education That Fits: Review of International Trends in the Education of Students with Special Educational Needs. Christchurch: University of Canterbury.

Naicker, S. (2015). The politics of inclusive education in South Africa. In F. Kiuppis and R.S. Hausstätter (Eds.). Inclusive Education Twenty Years After Salamanca. New York: Peter Lang.

Nikolić, G., Lukić, M. \& Janković, V. (2010). Deca i učenici sa smetnjama i teškoćama u razvoju u Republici Srbiji. Beograd: Zavod za napređivanje obrazovanja i vaspitanja

Nikolić, G., Nedeljković, M. (2015). Inkluzija u Srbiji - u potrazi za smislenim putem. Socijalna misao, 4, 9-19.

Popović,Z.\&Nikolić,G. (2015) Postignuća uчenika sa smetnjama u razvoju u zavisnosti od vrste wkole, nastavnog predmeta i vrste smetnje; Inovacije u nastavi, Uuiteljski fakultet u Beogradu (437-457)

Republic of Serbia. (2006). Zakon o sprečavanju diskriminacije osoba sa invaliditetom [The Law on the Prevention of Discrimination Against Persons with Disabilities]. Beograd [Belgrade]: Službeni glasnik RS, 33/06 [Official Gazette of the RS, 33/06].

Republic of Serbia. (2009). Zakon o osnovama sistema obrazovanja $i$ vaspitanja [The Law on the Fundamentals of the Education System]. Beograd [Belgrade]: Službeni glasnik RS, 72/09 [Official Gazette of the RS, 72/09].

Republic of Serbia. (2015). Zakon o udžbenicima [The Law of a Textbook]. Beograd [Belgrade]: Službeni glasnik RS, 33/15 [Official Gazette of the RS, 33/15].

Rodriguez, C.C. \& N. Garro-Gil (2014). Inclusion and integration on special education. Procedia: Science and Behavioral Sciences, 191, 1323-1327.

Rouse, M. \& Florian, L. (1996). Effective Inclusive Schools: a study in two countries, Cambridge Journal of Education, 26 (1), 71-85.

Shin, M. \& Pedrotty D.B. (2015). A synthesis of mathematical and cognitive performances of students with mathematics learning disabilities. Journal of learning disabilities , 48 (1), 96-112.

Stenhoff, D. M. \& Lignugaris-Kraft, B. (2007). A review of the effects of peer tutoring on students with mild disabilities in secondary settings. Exceptional Children, 74 (1), 8-30.

Steiner-Khamsi, G. \& Quist, H. (2000). The politics of educational borrowing: Reopening the Case of Achimota in British Ghana, Comparative Education Review, 44 (3), 272-299.

Swanson, H. L. (1999). Interventions for Students with Learning Disabilities: A Meta-analysis of Treatment Outcomes. New York: Guilford Press.

Swanson, H. L., Carson, C. \& Sachs-Lee, C. M. (1996). A selective synthesis of intervention research for students with learning disabilities. School Psychology Review, 25, 370-391.

Thurlow, M. L., Ysseldyke, J.E., Wotruba,J.W. \& Algozzine, B. (1993). Instruction in special education classrooms under varying student-teacher ratios. The Elementary School Journal, 93, 305-320.

UNICEF, Ministry of Education, and IPSOS, (2015). Analiza kvaliteta obrazovanja u školama i odeljenjima za obrazovanje dece sa smetnjama u razvoju, Beograd: Authors. [Online] Available: http://socijalnoukljucivanje.gov.rs/wpcontent/uploads/2016/06/analiza_kvaliteta_obrazovanja_u_skolama_i _odeljenjima_za_obrazovanje_dece_sa_smetnjama_u_razvoju.pdf 
United Nations, (2016). Sustainable Development Goals. New York: Author. [Online] Available: http://www.un.org/sustainabledevelopment/sustainable-development-goals/

Vaughn, Sh., Gersten, R. \& Chard, D. J. (2000). The underlying message in LD intervention research: Findings from research syntheses. Exceptional Children, 67 (1). 99-114.

Vigotski, L. S. (1996). Osnovi defektologije. Beograd: Zavod za udžbenike i nastavna sredstva.

Vislie, L. (2003). From integration to inclusion: focusing global trends and changes in the western European societies. European Journal of Special Needs Education, 18 (1), 17-35.

Vygotsky, L. S. (1925). Principles of social education for deaf and dumb children in Russia. In: International Conference on the Education of the Deaf, 227-235.

Zigmond, N. (2003). Where should students with disabilities receive special education services? Is one place better than another?, The Journal of Special Education, 37 (3), 193-199. 